\title{
Snow mold of winter cereals: a complex disease and a challenge for resistance breeding
}

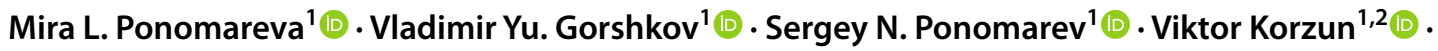 \\ Thomas Miedaner ${ }^{3}$ (])
}

Received: 1 July 2020 / Accepted: 4 November 2020 / Published online: 22 November 2020

(c) The Author(s) 2020

\begin{abstract}
Key message Snow mold resistance is a complex quantitative trait highly affected by environmental conditions during winter that must be addressed by resistance breeding.

Abstract Snow mold resistance in winter cereals is an important trait for many countries in the Northern Hemisphere. The disease is caused by at least four complexes of soilborne fungi and oomycetes of which Microdochium nivale and M. majus are among the most common pathogens. They have a broad host range covering all winter and spring cereals and can basically affect all plant growth stages and organs. Their attack leads to a low germination rate, and/or pre- and post-emergence death of seedlings after winter and, depending on largely unknown environmental conditions, also to foot rot, leaf blight, and head blight. Resistance in winter wheat and triticale is governed by a multitude of quantitative trait loci (QTL) with mainly additive effects highly affected by genotype $\times$ environment interaction. Snow mold resistance interacts with winter hardiness in a complex way leading to a co-localization of resistance QTLs with QTLs/genes for freezing tolerance. In practical breeding, a multistep procedure is necessary with (1) freezing tolerance tests, (2) climate chamber tests for snow mold resistance, and (3) field tests in locations with and without regularly occurring snow cover. In the future, resistance sources should be genetically characterized also in rye by QTL mapping or genome-wide association studies. The development of genomic selection procedures should be prioritized in breeding research.
\end{abstract}

\section{Introduction}

Snow mold is a disease complex caused by several phytopathogenic fungi that affect agricultural, ornamental, and indigenous plants under snow cover at or shortly below the freezing point (Bruehl 1982). Typically, snow mold is mainly reported from the Northern Hemisphere. There are four types of snow mold diseases, all caused by soilborne fungi or oomycetes: pink snow mold (Microdochium nivale,

Communicated by Rajeev K. Varshney.

Thomas Miedaner

miedaner@uni-hohenheim.de

1 Laboratory of Plant Infectious Diseases, FRC Kazan Scientific Center of RAS, Ul. Lobachevskogo 2/31, Kazan 420111, Tatarstan, Russian Federation

2 KWS SAAT SE \& Co. KGaA, Grimsehlstr. 31, 37555 Einbeck, Germany

3 State Plant Breeding Institute, University of Hohenheim, Fruwirthstr. 21, 70599 Stuttgart, Germany
M. majus), gray or speckled snow mold (Typhula idahoensis, T. ishikariensis, T. incarnata), snow scald (Myriosclerotinia borealis), and snow rot (Pythium iwayami and P. okanoganense) (Murray et al. 1999). Microdochium nivale (Fr.) Samuels \& Hallet and M. majus (Wollenw.) Glynn \& S.G. Edwards are the most common reasons for biotic winter crop damage (Nakajima and Abe 1996; Tronsmo et al. 2001).

The quantitative and qualitative composition of the snow mold-causing community greatly varies depending on the crop, region, and ecological conditions (Chang et al. 2006). In Russia, an analysis of 46 strains from five regions revealed that $59 \%$ of the strains were M. nivale and $28.3 \%$ were M. majus (Gagkaeva et al. 2020). Also, in the Central and Northwestern European regions of Russia, M. nivale is predominant and accounts for $64.7 \%$ of the analyzed strains from this territory. In 2020, M. seminicola M. Hern.-Restr., Seifert, Clear \& B. Dorn was first discovered in Russia (Gagkaeva et al. 2020). M. seminicola causes symptomless endophytic infections in cereals, and, from an ecological perspective, additional information about the distribution of this species would be essential. In the southern European 
region of Russia that is rarely affected by snow mold disease (Ivaschenko et al. 1997), M. majus and M. nivale were equally represented in cereals. On the contrary, in the central part of Russia (Tatarstan Republic) with sufficient snow cover each year, a regular annual occurrence of snow mold in winter rye was revealed for the period 2001-2017 (Ponomareva et al. 2019). The weighted average prevalence of snow mold in this period was $19.2 \%$, which is near the value that is accepted for a disease being an epiphytotic (20\%). In the Kirov region, $M$. nivale annual disease spread in winter ranged from 29 to $100 \%$ of the total growing area with a total loss of the cereal crops in nine out of 20 years (1999-2018, Sheshegova 2015; Utkina et al. 2019).

In the 1970s, snow mold was thought to be a disease that affected cereals only in those regions where plants were affected by prolonged ( $>100$ days) snow cover. For example, the northern areas of winter rye cultivation in Russia are characterized by long periods of humidity in autumn and early spring, higher snow cover, and frequent changes of snowy and thawing periods in winter, which induce fungal development (Glinushkin et al. 2018). However, today Microdochium species are seen as facultative snow mold pathogens that can also develop during the whole growing season of host plants (Matsumoto and Hsiang 2016) and produce symptoms of seedling blight, foot rot, leaf blight, and head blight.

Snow mold resulting from $M$. nivale infection is one of the most serious diseases of winter cereals (Tronsmo et al. 2001; Ergon et al. 2003; Prończuk et al. 2003; Ren et al. 2015), forage and turf grasses (Årsvoll 1973; Grosch and Schumann 1993; Abdelhalim et al. 2016; Stricker et al. 2017) in temperate and cold climatic zones. Mycelium, conidia, and ascospores are the infectious causes of $M$. nivale. No efficient crop protection strategy exists against these pathogens. Fungicides used so far are not environmentally friendly and many of them were recently prohibited in Europe (Gołębiowska and Wędzony 2009; Nielsen et al. 2013; Dyda et al. 2019). Also, it is impossible to spray fungicides under snow cover. The only chemical control mechanism available is seed dressing with fungicides that protects the germinating seed from seed-borne, but often not soil-borne inoculum. Thus, substantial effort must be invested in resistance breeding. However, the resistance of the most important cereal cultivars to this pathogen is not satisfactory or, in many cases, not existing. Rye is the hardiest cereal (Schlegel 2013; Fowler et al. 2014); however, it is also grown in Finland and in the northern zones of Russia, where winter wheat does not survive. Thus, rye must endure very low temperatures in winter periods with a long and high snow cover and is, therefore, prone to snow mold infections.

In this review, we concentrate on snow mold induced by Microdochium species that are harmful for all winter cereals. The focus is on rye, however, when results are missing, we also refer to winter triticale and winter wheat. The other winter cereals oat and barley do not play a role in Russia. In Central Europe, where winter barley is extensively grown, the occurrence of damaging snow mold is rare.

\section{Taxonomy, host range, and economic importance}

Microdochium nivale, a filamentous ascomycete that is haploid in its vegetative state, was firstly described by the Swedish mycologist E.M. Fries (1825) under the name Lanosa nivalis characterized by its ability to attack wheat and grass under snow cover (Noble and Montgomerie 1956). Due to its similarity with Fusarium species, this fungus was later named Fusarium nivale Ces. ex Berlese \& Voglino (Wollenweber 1931; Gerlach and Nirenberg 1982) and was reclassified in 1980 as Gerlachia nivalis (Ces. ex. Sacc.) W. Gams \& E. Müll. (Gams and Müller 1980). Shortly after, Samuels and Hallett (1983) assigned the species to the genus Microdochium.

The recognition of two varietas, primarily based on the difference in conidial dimensions and septation, was firstly proposed by Wollenweber (1931) as F. nivale var. nivale and $F$. nivale var. majus. A recent examination of the elongation factor 1 alpha $(E F-1 \alpha)$ gene sequence led to the reclassification of the two varietas of M. nivale as separate species, M. nivale (Fries) Samuels \& I.C. Hallett and M. majus (Wollenw.) Glynn \& S.G. Edwards (Glynn et al. 2005; Watanabe et al. 2011; Hayashi et al. 2014). M. nivale and M. majus can be differentiated by morphological means (Gerlach and Nirenberg 1982; Lees et al. 1995; HernándezRestrepo et al. 2016), quantitative real-time PCR (Nielsen et al. 2013; Sonia et al. 2018), molecular markers (Hayashi et al. 2014; Matušinsky et al. 2019), and gene-sequence analyses (Einax and Voigt 2003; Jewell and Hsiang 2013). Very recently, Abdelhalim et al. (2020) demonstrated that $M$. nivale isolates revealed genetic differences related to different host plants (grasses $v s$. cereals) and different geographic regions (Norway and UK vs. North America) based on gene sequencing. This supports the assumption that some host specialization exists among $M$. nivale.

The genetic differences between $M$. nivale and M. majus are poorly characterized since their genome sequences are absent in public databases. However, the genome structure (3589-3816 Mbp size, 7617-8080 of annotated genes) of these species was briefly described by Jewel (2013). The only Microdochium species for which the genome sequence is available is M. bolleyi (David et al. 2016).

Usually one of the Microdochium species is prevailing in a crop (Nicholson et al. 1996). M. majus has a higher prevalence than $M$. nivale in most years in all cereals except rye, in which M. nivale was found to be more common. This is 
substantiated by a study of Danish cereals where M. majus has been more common than $M$. nivale for the last 50 years in wheat, barley, and triticale (Nielsen et al. 2013). In a study from the UK, 64\% of infected samples involved M. majus and 36\% M. nivale in wheat (Doohan et al. 1998). Also, in spring cereals, both species were identified at significant amounts onto the seed and in seedlings (Nielsen et al. 2011; Jonavičienè et al. 2016). They reported an advantage in the fitness of M. majus over M. nivale in spring wheat, spring triticale and spring oats, whereas spring barley was more sensitive to M. nivale. In contrast, McNeil et al. (2012) found on the seed of spring oats almost exclusively $M$. nivale whereas in spring barley seed $M$. majus dominated. Realtime PCR confirmed the presence of both pathogens in the seedlings of all cereal species tested (McNeil et al. 2012). Simpson et al. (2000) reported that M. majus showed a selective advantage on winter wheat and winter oat seedlings and $M$. nivale showed a strong selective advantage on winter rye seedlings in a mixed inoculation trial. Cockerell et al. (2009) suggested that spring wheat and oats are at risk from high levels of Microdochium infection, and spring barley is also at risk but only at levels exceeding $30 \%$ seed infection. All studies agree that winter rye (Secale cereale L.) is mostly colonized by M. nivale (Płażek et al. 2011; Żur et al. 2011; Pociecha et al. 2013a).

Economically, snow mold is important in all northern countries. The presence of a prolonged snow cover and moderately warm temperatures from February to April contribute to the spread and development of the disease on a large territory of Russia, leading to significant yield losses in fields cultivated with susceptible varieties. For example, from 2017 to 2019 snow mold affected an area of 445,600 to 856,500 hectares in Russia (Review 2020). Snow mold has become an important disease of winter wheat in Latvia during the last several years (Bankina et al. 2012).

\section{Symptoms and pathogenicity}

Microdochium nivale and M. majus invade plants in late autumn or during the early winter period at low (near freezing) temperatures under dark and humid conditions of a snow cover where they proliferate and spread in the host tissues causing pink snow mold. M. nivale infects different parts and tissues of the plant both above and under the soil surface, starting from the endoderm and cortex of the root crown and then spreading to the epidermis of the leaves and leaf sheaths (Pociecha et al. 2013b). During infection, infectious hyphae penetrated directly into the cell wall of the epidermis with the help of a penetrating pin and then quickly spread in the host tissues both intercellularly and intracellularly (Kang et al. 2004). In this study, no entry of the host tissues via stomata was observed. Dubas et al.
(2011) determined that the infection in triticale was by hyphal growth starting at soil level, which then passed into the leaves of the plant, but this penetration occurred only through the stomata and was followed by the formation of haustoria, resulting in intracellular growth. Żur et al. (2011), observing an infectious process of $M$. nivale on rye, also found that numerous hyphae penetrated the leaves through stomata within days following inoculation. Mycelium grew out of the soil and gradually penetrated the cells of the cortex and vascular tissues and then spread out. As such, both studies agreed that $M$. nivale infection began at ground level and progressed vertically up the plants before entering the leaves via stomata.

Microclimatic conditions, especially the temperature and humidity of the environment, strongly influence the infection process (Smith 1981; Hömmö 1994; Sugiyama and Shimazaki 2007). Immediately after snow melt, the fungi show a pale pinkish mycelium in patches (Fig. 1) and/or orange sporodochia. After drying, the dead leaves form a compressed paper-like layer. The main effects of snow mold attack are a reduction of seed germination by seed-borne inoculum (Hudec and Muchova 2010) and pre- and postemergence death of seedlings leading to a significant reduction in grain yield (Humphreys et al. 1995). Since M. nivale can survive in the soil saprophytically for many years, inoculum will be available to attack crops despite a long absence of snow (Tronsmo 2013).

Both Microdochium species are not only causing pink snow mold symptoms under cool and humid conditions during spring and fall (Abdelhalim et al. 2020), but also seedling blight, foot rot (Clement and Parry 1998; Amein et al. 2007; Walker et al. 2009; Nielsen et al. 2011; Jørgensen et al. 2012), and head blight (Xu et al. 2007), the latter resembling the symptoms of Fusarium head blight (Gorkovenko et al. 2009; Gagkaeva et al. 2019). Late head blight infections also lead to seed-borne inoculum that could be a great problem in cereal stands for seed multiplication. In 2016, numerous reports on head blight and necrotic lesions on the flag leaves of winter wheat were observed in the Southern European region of Russia induced by both Microdochium species as shown by DNA analyses (Gagkaeva et al 2017). An extended period of wet and cool conditions might replace a long-lasting snow cover. Thus, Microdochium infections may become even more important with global warming, as they may prevail under conditions of large fluctuations in climatic variation and less seasonal predictability.

Miedaner et al. (1995) described the colonization of rye plants by $M$. nivale during the whole growth period by a species-specific enzyme-linked immunosorbent assay (ELISA). The highest fungal protein content was found in the plants directly after snow melt. During further rye growth, protein content decreased substantially, but showed a second peak between anthesis and full maturity. At milk ripening a foot 
Fig. 1 Natural snow mold infection of winter rye in Tatarstan/ Russia. a Yield plots of winter rye with a snow mold-resistant entry in the middle (April 2018); b the susceptible winter rye varieties in conditions of severe snow mold infection (May 2019); c, d Details of snow mold-infected plots with some surviving plants (May 2019)
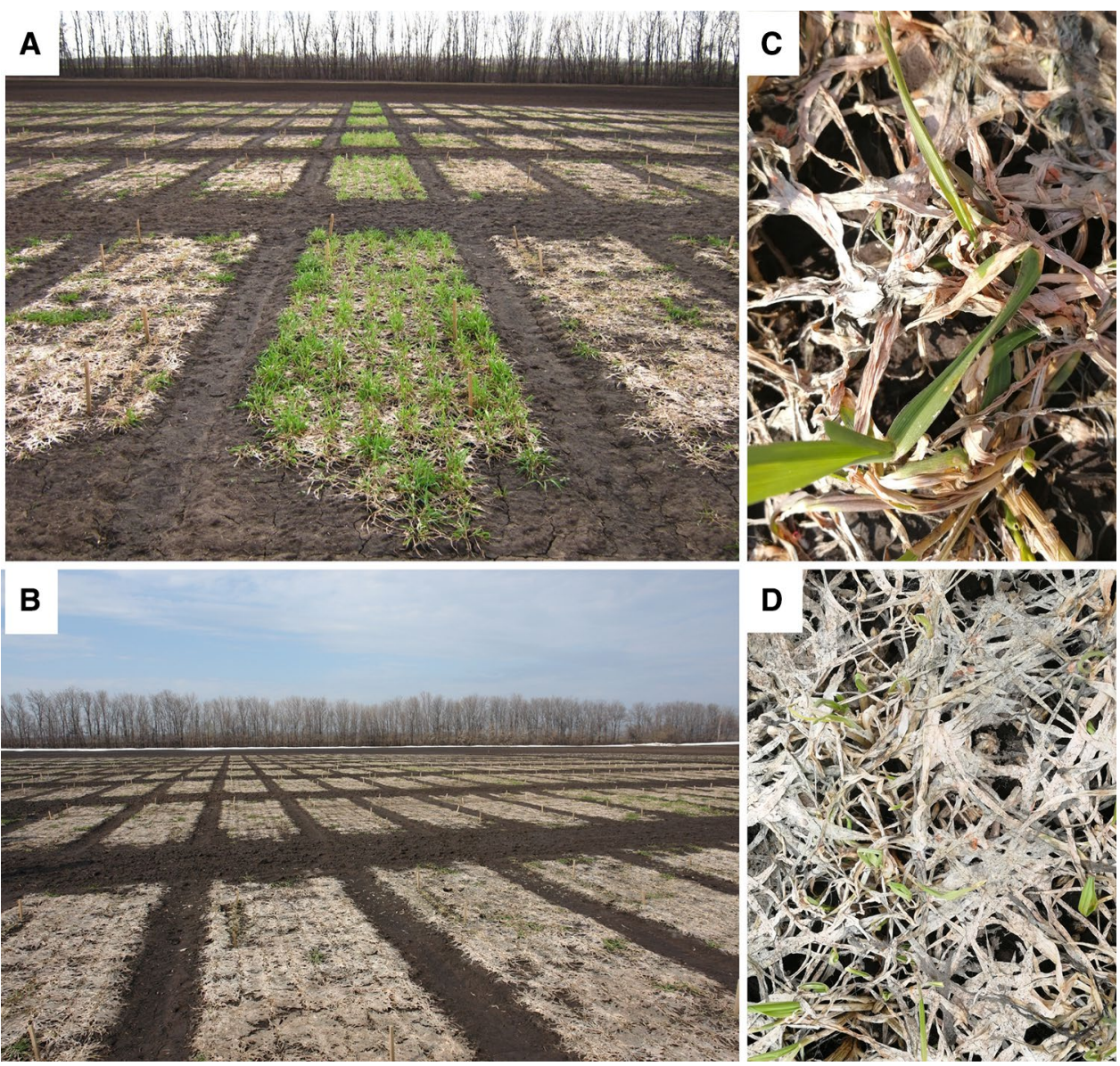

rot rating of 3.3 on the 1-9 scale was recorded. This clearly demonstrates that $M$. nivale is capable of damage also at later growth stages. Interestingly, there was no correlation between young and adult plant stages for the resistances of 12 inbred lines illustrating that resistance to snow mold and M. nivale induced foot rot are attributed to different defense mechanisms. Similarly, Maurin et al. (1995) found a moderate, but non-significant correlation $(r=0.358)$ between foot rot and head blight resistance in winter wheat.

Both $M$. nivale and $M$. majus can reproduce asexually and sexually (Litschko and Burpee 1987; Lees et al. 1995; Parry et al. 1995), and the teleomorph belongs to Monographella. In a study of $M$. nivale isolated from grasses and cereals in Canada, most strains did not produce perithecia in vitro (Smith 1983). Some cereal strains formed these structures more frequently than others, but most of the perithecia did not mature. Mating type genes and reproductive strategy in $M$. nivale fungi are not yet fully understood. Fertility can be disturbed in many ways not only by genetic factors but also by environmental factors such as temperature, light, humidity, substrate, and physical factors that can affect different stages of development or the function of perithecia (Matsumoto and Hoshino 2008).
It is extremely important to note that Microdochium species do not form secondary metabolites toxic to mammals and humans (Edwards 2004; Glynn et al. 2005; Kabak et al. 2006; Xu et al. 2007) and accompany as endophytes plants throughout their life cycle.

\section{Measures for controlling snow mold}

For the control of snow mold, agronomic measures, fungicides, and biological control have been examined. Also, sowing time, fertilizer application, and residue management can be used to manage snow mold. It is important that the plants are not developed too far when snow arrives, because dense plant stands can be faster colonized by the fungi.

Crop rotation is another important measure for control. Inclusion of spring annual or non-host crops in rotations leads to a rapid decrease in snow mold disease potential, probably due to reduced inoculum density in soil and changes in soil microbe populations (Murray et al. 1999; Gossen et al. 2001). In addition, after crop rotations with legumes such as alfalfa, sweet clover, or pea, less snow mold occurs on wheat, but with each subsequent sowing of winter wheat its severity increased (McKey and Reader 1953). 
Concerning fertilizer, Dempsey et al. (2014) demonstrated phosphate $\left(\mathrm{PO}_{3}{ }^{3-}\right)$-mediated inhibition of $M$. nivale and M. majus. In vitro experiments have shown a direct inhibitory effect on the mycelial growth of both species. Inhibition of mycelial growth in planta would allow increased time for initiation of host defenses, and the combination of direct and indirect effects is likely to contribute to the reduced susceptibility of some genotypes. However, the application of $\mathrm{PO}_{3}{ }^{3-}$-containing fertilizers in the field has to be examined in greater detail.

Autumn-sown cereals are generally seed-dressed with fungicides in Northern Europe, thus reducing the risk of seedborne $M$. nivale. The attack of soilborne inoculum is reduced only for the first days of germination, but not in later stages of seedling development. The challenge of fungicide application is related to the fact that the activity of the pathogens occurs in the period when direct treatment of plants is difficult or impossible. Since the pathogen can reduce germination and also attack at later stages of plant development, a greater risk of plant losses by seed-borne inoculum occurs in organic farming (Johansson et al. 2003).

Numerous chemical protective agents used to combat both pathogens are available varying in their uptake and biochemical mode of action. The activity of the pathogen is inhibited by intervention in fungal mitosis, reduction of respiratory enzyme activity, inhibition of sterol, DNA and RNA synthesis, restriction of amino acid uptake, or inhibition of ATP production (Smiley et al. 1992; Yang et al. 2011).

Fludioxonil is highly effective for controlling $M$. nivale and M. majus by seed treatment (Glynn et al. 2008; Walker et al. 2009). However, resistances to strobilurines have already been reported in the same studies. Higher contents of M. majus and M. nivale DNA were identified in seedlings emerged from untreated seeds compared with the seedlings emerged from fludioxonil-treated seeds (Jonavičienè et al. 2016). Reports on the effect of tebuconazole were inconsistent (Simpson et al. 2001; Walker et al. 2009; Jonavičienè et al. 2016).

Much research has been devoted to the development of alternative, more environmentally friendly methods, such as the use of natural biocontrol agents (Compant et al. 2005; Haas and Défago 2005; Palazzini et al. 2013). Among them, the usage of Pseudomonas brassicacearum MA250 (Levenfors et al. 2008; Andersson et al. 2012), Acremonium boreale (Smith et al. 1989), and two strains of Bacillus sp., YKT 2-17 and MGD-11 (Hoshino et al. 2004), were successful. Alternatively, the use of the nematofauna (mycohelminths Aphelenchoides saprophillus Franklin, Paraphelenchus tritici Baranovskaya, Aphelenchus avenae Bastian) for decreasing the damage on winter wheat infected with pink snow mold was analyzed (Tkachenko et al. 2015). Applied in autumn, a water suspension based on A. saprophillus on winter wheat in a dose of 160,000 individuals $\mathrm{m}^{-2}$ reduced disease incidence in spring threefold, thus increasing grain yield by $14.4 \%$.

In conclusion, the best measures to limit snow mold damage in winter cereals are to regulate the nutrition of the plants increasing their winter hardiness, crop rotation, chemical seed treatment, and the introduction of resistant varieties (Murray et al. 1999).

\section{Physiological factors affecting infection and symptom expression}

In general, a stable snow cover on unfrozen soil provides insulation, darkness, and humidity, creating favorable conditions for the snow molds (Bruehl and Cunfer 1971). These conditions reduce competition with other soil-borne pathogens that require higher temperatures (Hsiang et al. 1999; Chang et al. 2006) and limit the photosynthetic activity of the plant, thus weakening its protective responses (Murray et al. 1999; Matsumoto 2009). Reduced photosynthetic activity also limits the resources available for the pathogens resulting in increased interspecific competition (McBeath 2002). Although the inoculum density of pathogens is high in many growing regions, the environmental conditions required for disease development are much less predictable and consistent. Many other factors contribute to winterkill of cereal stands, including freezing conditions without snow.

The specific environmental conditions that contribute to the disease make it extremely difficult to reproduce experiments for evaluating resistance to snow mold (Kruse et al. 2019). Most of the studies on snow mold resistance used cold acclimation as a pre-treatment. The maximal resistance was detected exclusively in cold-hardened plants (Miedaner et al. 1993; Hömmö 1996; Laroche et al. 1997), but genotypes differ in their ability to obtain cold-induced resistance (Tronsmo, 1994; Pulli et al. 1996; Gołębiowska and Wędzony 2009; Kondo et al. 2012). It was shown that cold acclimation is necessary for the initiation of the defense system against snow mold infection (Nakajima and Abe 1996; Ergon et al. 1998; Tronsmo et al. 2001; Gołębiowska and Wędzony 2009; Płażek et al. 2011). According to Gaudet and Kozub (1991) and Gaudet (1994), there is no direct correlation between snow mold resistance and frost tolerance, but cultivars with high frost tolerance often show higher persistence in response to snow mold. On the other hand, young plants already killed by frost are, of course, not able to show any snow mold resistance. Thus, no strong correlation was found between snow mold resistance and frost tolerance in winter wheat (Bruehl 1982; Gaudet and Kozub 1991) and perennial ryegrass (Hofgaard et al. 2003). Recovery after pathogen attack depends on the survival of crowns, which are the reservoir of soluble carbohydrates used for regrowth after stress cessation. 
In winter cereals, snow mold severity interacts with winter hardiness or frost tolerance in a complex way. Several physiological traits are suspected or known to influence snow mold resistance (SMR) in winter cereals including plant size (Bruehl and Cunfer 1971), carbohydrate accumulation and metabolism (Kiyomoto 1987; Mohammad et al. 1997; Kawakami and Yoshida 2012; Yoshida and Kawakami 2013; Meguro-Maoka and Yoshida 2016), and the regulation of genes for defense-related proteins, transcription factors, and kinases during the cold-hardening process (Gaudet et al. 2011; Gaudet and Laroche 2013). However, the relationship between frost tolerance and snow mold resistance is not well understood. Evidence suggests that they are not controlled by the same genes for winter cereals, although some common physiological processes might be involved. When plants are exposed to one stress factor, this can change their reaction to another stress factor, either biotic or abiotic. For example, freezing stress generally increases the susceptibility of plants to fungal attack and, on the contrary, infection of the plant by pathogens during winter reduce their resistance to frost.

Besides these effects, temperature also plays a crucial role for the fungi. Microdochium species are usually cited as a common cause of cereal diseases in cooler regions (Daamen et al. 1991; Nakajima and Abe 1994; Tronsmo et al. 2001; Bertrand et al. 2009). This could be attributed to the dramatic inhibition of their in vitro growth at temperatures $>25^{\circ} \mathrm{C}$. This was confirmed from other studies in European countries that showed that $M$. nivale isolates grew optimally at 20-25 ${ }^{\circ} \mathrm{C}$ (Brennan et al. 2003; Doohan et al. 2003) or even $<20^{\circ} \mathrm{C}$ (Hudec and Roháčik 2003). In synthetic media, the fungi can grow at temperatures as low as $-6{ }^{\circ} \mathrm{C}$ and in the field at temperatures below $0{ }^{\circ} \mathrm{C}$ (Hömmö 1994; Ergon et al. 2003).

\section{Candidate genes and genomics of host resistance}

Snow mold resistance (SMR) is a complex quantitative trait manifesting as a continuous distribution of disease response that is highly influenced by environmental conditions (Kruse et al. 2017). Further, like other complex quantitative traits, SMR is conferred by numerous quantitative trait loci (QTL) and influenced by genotype $\times$ environment interactions since the environment affects not only host resistance but also the composition of the pathogenic complex that causes the disease.

A potential role in defensive response to $M$. nivale infection was proposed for catalase, peroxidase, and thiolspecific antioxidant proteins (Gołebiowska-Pikania and Golemiec 2015) in winter triticale. Recently, Gołebiowska et al. (2019) concluded that genotype and cold treatment significantly affected the amount of small proteins in winter triticale leaves. The pattern of these proteins could be correlated with the level of the resistance to pink snow mold infection. Four cold-accumulated proteins: ADP-binding $38 \mathrm{kDa}$ resistant protein, $\beta$-ATP synthase subunit, as well as $25 \mathrm{kDa}$ and $49 \mathrm{kDa}$ thioredoxin peroxidases, can play a role in preparing the plant for the attack of a fungal pathogen in a resistant winter triticale, maintaining the redox balance and energy pathway in the seedling leaves. The research carried out by the authors can point to molecules for further analysis of the $M$. nivale pathogenesis process in winter cereals.

Nevertheless, these proteins are only a part of a complex mechanism that is still not fully understood yet. Kuwabara and Imai (2009) proposed a model of a signalizing network for disease resistance acquired through cold acclimation that includes three pathways: (1) defense pathways mediated by salicylic or jasmonic acids, (2) cold acclimation by coldbinding transcription factors, and (3) novel, still unknown pathways. Moreover, disease resistance is also related to physiological adaptation that leads to the accumulation of storage carbohydrates during cold acclimation (Gaudet et al. 1999). According to the findings of Płażek et al. (2011), a link between the resistance to $M$. nivale and a higher content of total carbohydrate concentrations in inbred lines of winter rye exists. Żur et al. (2013) demonstrated that chitinases are actively involved in the response of triticale plants to M. nivale infection. The activity of both studied glucanhydrolases is suppressed during the cold, possibly as a consequence of an altered metabolism. Thus, the total activity of chitinases in plants might be indicative for the plant's resistance/susceptibility against a fungal pathogen.

Szechyńska-Hebda et al. (2016) have shown that the cellulose in the cell walls of resistant triticale varieties after cold treatment has a more compact and integrated structure with thicker and longer fibers than that of the respective susceptible variety. This structure of cellulose limits water sorption, promotes stronger binding of crystallization water with macromolecules, prevents depolymerization during decomposition, and ultimately leads to the higher thermal stability of the cell wall. Besides these detailed studies, the mechanisms of resistance to pink snow mold during winter are far from being understood.

As a tool for further dissecting SMR, genomic data could be extremely helpful. In the first study on QTL mapping in winter triticale, QTL associated with resistance components to $M$. nivale was detected on chromosomes $1 \mathrm{~B}$, $2 \mathrm{~A}, 3 \mathrm{~A}, 3 \mathrm{~B}, 5 \mathrm{~A}, 5 \mathrm{~B}, 6 \mathrm{~A}, 6 \mathrm{~B}$, and $7 \mathrm{~B}$ in climate-chamber tests (Szechyńska-Hebda et al. 2013). Surprisingly, no rye chromosome carrying SMR loci was found in this study. However, this might be explained by the source of the rye genome used for the primary triticale crossing.

Also, in winter wheat, there have only been limited reports on QTLs for SMR. Kruse et al. (2017) detected 
two QTLs. One of them was associated with both freezing tolerance and SMR on chromosome 5A. This QTL was closely linked with the Fr-A2 (Frost-resistance A2) locus. The association of both traits may have resulted from pleiotropic effects or from the fact, that higher tolerance to low temperatures enabled the plants to better defend themselves against snow mold.

Lozada et al. (2019) reported the first major study on the genomics of SMR by using genome-wide association study (GWAS) and genomic selection (GS) approaches in winter wheat. This research identified genomic regions in diverse populations of US winter wheat lines from the Pacific Northwest region (PNW). A total of 14 linked snow mold resistance markers were identified on chromosome 5A. Some of these significant SNPs co-localized with the freezing tolerance $\mathrm{Fr}$-A2 locus and others coincided with the major vernalization gene $V r n-A 1$. Additional SNP markers on chromosomes other than $5 \mathrm{~A}$ and $6 \mathrm{~B}$ were identified that have not been reported elsewhere, and hence may represent novel QTLs affecting snow mold tolerance in PNW winter wheat. Nevertheless, detected regions on chromosomes $5 \mathrm{~A}$ and $6 \mathrm{~B}$ may be syntenic between wheat and triticale and could give a good start for investigations in other related cereals crops, e.g., rye.

Kovi et al. (2016) conducted a major study of whole transcriptome sequencing (RNA-seq) in order to understand the response of Lolium perenne to an early infection of $M$. nivale. Transcriptomic changes in perennial ryegrass during early infection were detected. Some of the differentially regulated genes were found to be disease-related proteins, calmodulin-binding proteins, lipid transfer proteins, and flavonoid biosynthesis. The list of suspected candidate defense associated genes and cell morphogenesis associated genes identified in this study may provide a good scientific basis for further research toward understanding the host-pathogen interactions and describing the molecular mechanisms of SMR.

For dissecting individual components of SMR and to accelerate breeding progress in winter rye, research on genomic tools should be prioritized. Generally, genomic resources in rye are limited as recently reviewed by Miedaner et al. (2019). Shortly, there is one inbred line (Lo7) where recently a whole-genome sequencing was finished and medium- to high-density SNP assays are available. Alternatively, DArTSeq can be commercially performed in the rye. This suffices for all marker-based methods; however, the availability of functional gene sequences is very limited. Genome-wide association studies (GWAS) would allow to screen large numbers of genotypes. For selected, highly effective resistance sources, also a bi- or multi-parental QTL mapping could be taken into account, because this allows the localization of the respective genomic regions with higher precision. These experimental approaches could be combined for gaining a broad training population for genomic selection (GS) procedures. Due to the complex host-pathogen interaction and the quantitative nature of SMR, this technique could play a key role in improving the resistance in winter cereals as shown by many examples of other diseases caused by hemi-biotrophic fungi.

Combining GS with phenotypic selection will increase the genetic gain by selecting lines with improved tolerance to winter freezing and SMR based on genomic-estimated breeding values. In addition, progress could also be achieved by analyzing the transcriptome profile of susceptible vs. resistant winter rye inbred lines during different stages of host colonization by Microdochium. This tool will serve to characterize early signaling events during the host-snow mold interaction and could result in a list of candidate genes crucial for resistance reaction. By the combination of genomic and transcriptomic data, candidate genes for SMR could be verified more effectively in order to overcome the inherent weaknesses of each individual method. In rye, however, no such studies were conducted till now.

\section{Testing and breeding for snow mold resistance}

In cereals, a quantitative variation exists among cultivars for SMR with relatively high heritability that is conditioned by the additive effects of many loci (Iriki and Kuwabara 1993). Breeding for SMR faces several challenges. In the field, the length of snow cover is not predictable, other snow mold fungi might interact even when M. nivale or M. majus are inoculated, and in each year the overwintering conditions greatly vary. Moreover, injuries due to snow mold can hardly be differed from other causes of winter damage, e.g., ice encasement, carbohydrate depletion, low photosynthetic efficiency (Ergon et al. 1998). Therefore, to identify SMR techniques are needed for use under controlled conditions mimicking the snow cover with high precision (Gaudet and Bhalla 1988). Additionally, M. nivale isolates may lose their pathogenicity rather soon when cultivated on laboratory media (Johansson et al. 2003).

Under controlled conditions of climate chambers, in which plants are exposed to low temperatures for hardening, inoculation, and incubation, tests could be conducted throughout the year (Sunderman 1964). The degree of the disease can be controlled by varying the duration of incubation at low temperatures. The temperature should be adjusted to the cereal species. Rye, for example, needs lower temperatures $\left(-4{ }^{\circ} \mathrm{C}\right)$ to stop vegetative growth than wheat (Schlegel 2013). The optimal conditions for the development of snow mold on winter wheat in a controlled environment have been identified by Gaudet and Kozub (1991) and are presented in Fig. 2. 
Preparation of $M$. nivale inoculum for testing winter cereals was described by Prończuk and Prończuk (1987). A prehardening of test plants is highly important for the outcome of the test (Miedaner et al. 1993). Plant regrowth was evaluated using the Average Regrowth Index (ARI), i.e., a visual rating scale from 0 to 5 , where ' 0 ' denotes a plant without any visible symptoms of infection and ' 5 ' a completely dead plant with no signs of leaf elongation.

According to Hömmö (1994), the results obtained in the field were closely correlated with those obtained in the climate chamber. Jamalainen (1974) reported that some results in the snow mold chambers are in conflict with those in the fields. Accordingly, Miedaner et al. (1993) found significant, but moderate correlations ( $r=0.51-0.57, P<0.01$ ) between growth-chamber results and a 2-year field test across 21 rye inbred lines. Because of its utmost importance for breeding, this correlation should be investigated with larger populations.

The breeding methods currently deployed for the identification of SMR in winter cereals in Russia are based on phenotypic screening in the field especially since natural conditions are predisposed to evaluation. For breeding programs in a number of other European countries, evaluation in climate chambers are used. However, a combination with field trials should be most advantageous.

Identifying resistance sources and visual selection for SMR has been proved difficult, because of the close

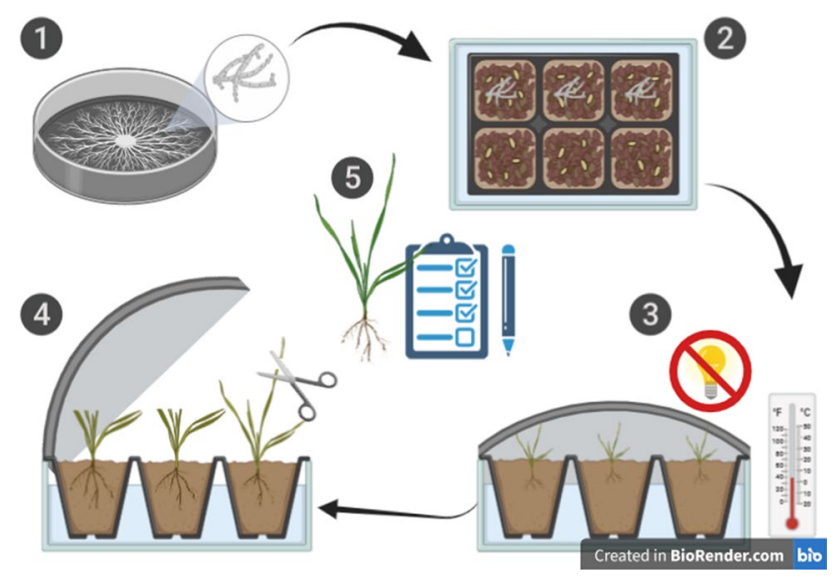

Fig. 2 Detailed scheme for testing SMR in climate chambers: (1) Mycelium was grown on Potato Dextrose Agar (PDA) for 1-2 weeks at $19{ }^{\circ} \mathrm{C}$ in darkness. (2) Mycelium was transferred to a sterile mixture of soil, peat, and sand (3:1:1 by volume), containing $5 \% \mathrm{w} / \mathrm{w}$ of ground wheat grain, and cultured for 14 days; inoculum was gently mixed and spread onto the soil of each plant. (3) Imitation of the conditions occurring under the snow cover by covering the plants with moist (watering) cellulose tissue paper (blotting paper) and a black plastic bag, placed in a cold chamber at $0-2{ }^{\circ} \mathrm{C}$ in darkness for 5-8 weeks. (4) The plants were cut at $5 \mathrm{~cm}$ above the soil surface and allowed to regrow for 3 days at $12{ }^{\circ} \mathrm{C}$ in $100 \mu \mathrm{mol} \mathrm{m} \mathrm{m}^{-2} \mathrm{~s}^{-1}$ PPFD light and next for 7 days at $18{ }^{\circ} \mathrm{C}$ in $250 \mu \mathrm{mol} \mathrm{m} \mathrm{m}^{-2} \mathrm{~s}^{-1}$ PPFD light. (5) Estimation of Average Regrowth Index (ARI) interaction of the overwintering ability of the host and quantitative host resistances (Murray et al. 1999). To select for entries with high winter hardiness, SMR, and additionally favorable agronomic traits, especially grain yield, different progeny tests are necessary: (1) Freezing tests at $-10{ }^{\circ} \mathrm{C}$ to $-23{ }^{\circ} \mathrm{C}$ depending on the cereal species to select for tolerance to sub-zero temperatures without snow cover, (2) climate-chamber tests for SMR at $0{ }^{\circ} \mathrm{C}$ to $+2{ }^{\circ} \mathrm{C}$ with simulation of a snow cover, and (3) field tests at several locations with/without regular snow mold incidence. Multienvironment tests are absolutely necessary, because the winter conditions, esp., length of snow cover and freezing temperatures, cannot be predicted and even the more resistant progenies will suffer when a sufficiently strong attack of snow mold occurs (Gaudet 1994; Nissinen 1996; Matsumoto and Hoshino 2013).

For assessing SMR in practical breeding, several indicators that characterize the degree of resistance have been successfully applied. Firstly, breeders use the estimation of regrowth, after artificial or natural infection. Average Regrowth Index (ARI) was calculated according to the formula: $[(n \times 0)+(n \times 1)+\cdots+(n \times 5)] \times N-1$, where: $n=$ number of plants corresponding to each disease rank (0-5), and $N=$ total number of observations. The lower the ARI value, the higher the resistance of the plants to the pathogen. Secondly, tillering is considered as an important resistance trait. The number of infected tillers after snow melt compared to the number before overwintering is a successful indicator of the selection of resistant lines. Finally, an extremely important trait is the yield of an entry after $M$. nivale attack, which ultimately shows the genetic ability to withstand an attack by $M$. nivale infection, especially in years with a strong fungal development. Besides these direct traits for assessing SMR, an important secondary trait is the time till maturity, because a high infection rate slows down further cereal growth. Susceptible varieties may come 1-2 weeks later to maturity than resistant varieties.

In breeding programs aimed at increasing the level of SMR, the availability of effective resistance sources is crucial. An early study of SMR in the US Pacific Northwest showed that out of 12,000 wheat samples collected from around the world, ten quantitatively resistant samples were the only lines statistically identified as resistant (Bruehl 1982). This screening resulted in the development of the Sprague variety with a useful level of quantitative resistance to pink snow mold. SMR among winter wheat cultivars from other countries also has been reported (Amano and Osanai 1983; Gaudet and Kozub 1991; Brennan et al. 2005; Serenius et al. 2005).

In rye, also various sources of resistance were identified by different authors (Table 1). Kobylyansky and Solodukhina (2012) found sources of SMR among wild species and varieties of cultivated rye growing in the mountainous 
regions of the Caucasus and the Alps on the border of permanent agriculture following Vavilov's (1964) suggestion to search for resistance sources in the regions of the coevolution between host and pathogen. Alpine zones are characterized by the presence of a continuous snow cover over an extended period of time. Several authors showed that the number of sources with a durable resistance is very limited, especially in winter triticale. The work on the identification of new resistant varieties, which have not been previously used in breeding, was practically not carried out in recent years. The greatest number of winter rye varieties and lines resistant to snow mold have been found in the Federal Research Center N.I. Vavilov All-Russian Institute of Plant Genetic Resources (St. Petersburg) due to the engagement of the curators (see Table 1). It should be noted that there are no varieties that are not attacked by snow mold, and there is no systematic information on the inheritance of
SMR resistance in the different sources. Therefore, the use of genetically diverse sources of resistance is indispensable for durable SMR in winter cereals. Since additive inheritance of resistance to $M$. nivale prevails, increasing SMR by recurrent selection should be successful.

\section{Conclusions and further research needs}

Snow mold is one of the most difficult to manage plant diseases due to several reasons. First, despite its big economic importance, snow mold is rather poorly investigated, because it was thought to be important only for those regions where snow cover is maintained for a long period. However, during the past decades Microdochium species appeared to parasitize not only during early spring under snow cover, but also during the whole lifetime of the plant resulting in foot

Table 1 Summary data of resistance sources for Microdochium nivale in winter cereals

\begin{tabular}{|c|c|c|}
\hline Cereal & Germplasm & Reference \\
\hline Winter wheat & $\begin{array}{l}\text { Eltan (PI536994), Bruehl, Masami, Stephens, Xerpha, Mad- } \\
\text { sen, P.I.173438, P.I.172582, C.I.14106 (USA) } \\
\text { Cubus (Germany), } \\
\text { Folke, Sleipner, Renan, Arminda, Munstertaler, Saint-Johann } \\
\text { (Sweden), } \\
\text { Linna, Aura, Vakka (Finland) } \\
\text { Imeni Rappoporta, Mironovskaya 808, Zarya, Moskovskaya } \\
39 \text { (Russia) }\end{array}$ & $\begin{array}{l}\text { Kleijer (1988), Peterson et al. (1991), Hömmö and Pulli (1993), } \\
\text { Kuwabara et al. (1996), Jones et al. (2001, 2010), Tkachenko } \\
\text { et al. (2015) }\end{array}$ \\
\hline Winter rye & $\begin{array}{l}\text { Varieties-Tatarskaya 1, Estafeta Tatarstana, Zilant, Lisit- } \\
\text { syna, Kaluga 45, Kamalinskaya 13, Taezhnaya, Kirovskaya } \\
\text { 89, Vyatka 2, Dymka, Flora, Grafinya, Rosinka, Ilim, } \\
\text { Falenskaya 4, Purga, Chulpan, Chulpan 3, Ilmen, Iset, Super } \\
\text { Baby 2, Volna, Korotkostebelnaya 6, Kharkovskaya 88, } \\
\text { Bezenchukskaya 88, Volkhova, } \\
\text { S. cereale ssp. tetraploidum -Shatilovskaya tetra, Populyat- } \\
\text { siya I-82 tetra, Sibirskaya krupnozernaya } \\
\text { Accessions from VIR World Collection (N.I. Vavilov All- } \\
\text { Russian Institute of Plant Industry, St. Petersburg): } \\
\text { LAD-287, 1313, 11,349, 11,350, 11,357, 11,358 (Poland), } \\
\text { Epos, Rerus (Germany), } \\
\text { 11,330-11,334 (Sweden), } \\
\text { Lassaer (Austria) } \\
\text { Kevsole, Kefermarkter, Edelhofer, Toivo, 11,363, 10,953 } \\
\text { (Finland), } \\
\text { Münstertaler, Haunsberg, Niederndorferberg (Switzerland) } \\
\text { Feniks (Belgium), } \\
\text { 11,385 (Yugoslavia), } \\
\text { 11,150, k-11389 (Portugal), } \\
\text { 11,306 (Argentina), } \\
\text { 11,179, k-11180 (USA), } \\
\text { 11,388 (Tajikistan), } \\
\text { 11,398 (Georgia), } \\
\text { 11,131 (Azerbaijan), } \\
\text { Belta tetra (Belarus), } \\
\text { Beve, Borotba (Ukraine) } \\
\text { 11,340 (France) }\end{array}$ & $\begin{array}{l}\text { Tkachenko et al. (2015), Utkina et al. (2017), Ponomareva et al. } \\
\text { (2019) }\end{array}$ \\
\hline Winter triticale & $\begin{array}{l}\text { Hewo, Modus (Poland) } \\
\text { Sv } 856,003 \text { (Finland) }\end{array}$ & Gołębiowska and Wędzony (2009), Hömmö and Pulli (1993) \\
\hline
\end{tabular}


rot, leaf blight, and head blight. These non-snow mold associated diseases of Microdochium spp. must be researched more intensively, because they occur also in regions without harsh winter. Also, the correlation of resistance among the different diseases must be analyzed. In Fusarium diseases, we had to learn that each plant growth stage resulted in a different resistance ranking of the genotypes. In addition, information on the correlation between resistance to Microdochium spp. and to other species of the snow mold complex is missing.

Second, although some varieties with quantitative SMR exist, most of the germplasm is highly susceptible to this disease, and only a small number of resistance sources is known in any winter cereal. Moreover, multiple testing environments are required for breeding since SMR is a complex quantitative trait that is highly dependent on environmental factors.

Third, given that the parasitic cycle of snow mold causing fungi proceeds mostly under the snow cover, spraying of fungicides is complicated or even impossible and, thus, the soil-borne inoculum cannot be controlled.

Fourth, snow mold-causing fungi, including Microdochium nivale and $M$. majus, are poorly characterized by molecular means. Knowledge on virulence factors as well as full genome sequences is missing, and even the molecular features of host infection are totally unknown. Finally, no robust and reliable experimental models for studying the mechanisms of host interactions with snow mold-causing pathogens are worked out. Phenotypic standardization is necessary because the disease manifestation after artificial inoculation of plants in the field or in vitro is highly affected by several environmental factors controlling both pathogen development and host resistance. For example, the exact growth stage and the nutritional status of the plants under snow mold attack are as important as the length of snow cover or the duration and peak temperatures of the freezing period without snow.

In practical breeding programs, the selection of SMR requires parallel testing for increased freezing tolerance and for artificial infection of $M$. nivale in separate climate chambers. At the same time, elite lines need to be evaluated in field trials in regions with a reliable snow cover. While selecting resistant genotypes, both a fast regrowth and a high grain yield after infection should be evaluated.

In future, reliable experimental models should be worked out for studying the molecular basis of pathogen virulence and plant resistance. In addition, priming of physiological resistance (e.g., conferred by cold acclimation or other treatments) should be preciously exploited as a way to control snow mold. The use of natural biocontrol agents might be promising since snow mold-causing fungi seem to be less competitive compared to pathogens thriving during the growth period, and so, the search and application of psychrophilic bacterial and fungal strains or nematode biotypes which protect plants could reduce the risk of crop loss.

Breeding progress can be accelerated by identifying new and effective resistance sources, by researching the genetic factors controlling host resistance, and by improving and standardizing screening methods. Due to the complexity of the resistance mechanisms, a poorly understood genetic background, and strong interaction with winter weather conditions, it is difficult to increase the resistance of winter rye only via conventional breeding methods. In future, modern genomics-based techniques should be applied to large plant populations with accessions of different origin to establish QTLs responsible for both SMR and freezing tolerance. On this basis, genomic selection procedures could be established, e.g., by estimating genomic breeding values for SMR with using important QTLs for freezing tolerance as fixed effects (Herter et al. 2019). Winter rye could play a key role in this research caused by its high genetic diversity as cross-pollinated species, the high freezing tolerance, and the availability of new, marker-based resources (Miedaner and Wilde 2019). In future, SMR will be an important trait for successfully growing winter cereals in areas of higher latitude, like in Finland, Russia, and Canada, in a more sustainable way.

Author contribution statement MLP, VYG, and SNP provided the literature and made the draft manuscript. TM and VK thoroughly revised it. All authors read the final version for publication.

Funding Open Access funding enabled and organized by Projekt DEAL. MLP, VYG, SNP, VK were supported by the Ministry of Science and Higher Education of the Russian Federation (Grant No. 075-15-2019-1881).

\section{Compliance with ethical standards}

Conflict of interest The authors declare that they have no conflict of interest.

Ethics approval The authors declare that the experiments comply with the current laws of Germany and Russia.

Open Access This article is licensed under a Creative Commons Attribution 4.0 International License, which permits use, sharing, adaptation, distribution and reproduction in any medium or format, as long as you give appropriate credit to the original author(s) and the source, provide a link to the Creative Commons licence, and indicate if changes were made. The images or other third party material in this article are included in the article's Creative Commons licence, unless indicated otherwise in a credit line to the material. If material is not included in the article's Creative Commons licence and your intended use is not permitted by statutory regulation or exceeds the permitted use, you will need to obtain permission directly from the copyright holder. To view a copy of this licence, visit http://creativecommons.org/licenses/by/4.0/. 


\section{References}

Abdelhalim M, Brurberg MB, Hofgaard IS, Rognli OA, Tronsmo AM (2020) Pathogenicity, host specificity and genetic diversity in Norwegian isolates of Microdochium nivale and Microdochium majus. Eur J Plant Path 156:885-895. https://doi.org/10.1007/ s10658-020-01939-5

Abdelhalim M, Rognli OA, Hofgaard IS, Østrem L, Tronsmo AM (2016) Snow mould resistance under controlled conditions and winter survival in the field in populations of perennial ryegrass, meadow fescue, and Festulolium are partly dependent on ploidy level and degree of northern adaptation. Can J Plant Sci 96(4):579-589. https://doi.org/10.1139/cjps-2015-0259

Amano Y, Osanai S (1983) Winter wheat breeding for resistance to snow mold and cold hardiness. III. Varietal differences of ecological characteristics on cold acclimation and relationships of them to resistance. Bulletin of Hokkaido Prefectural Agricultural Experiment Stations 85-003176 CIMMYT

Amein T, Omer Z, Welch C (2007) Application and evaluation of Pseudomonas strains for biocontrol of wheat seedling blight. Crop Prot 27:532-536. https://doi.org/10.1016/j.cropro.2007.08.007

Andersson PF, Levenfors J, Broberg A (2012) Metabolites from Pseudomonas brassicacearum with activity against the pink snow mould causing pathogen Microdochium nivale. Biocontrol 57(3):463-469

Årsvoll K (1973) Winter damage in Norwegian grasslands, 1968-1971. Meld Norg LandbrHøgsk 52(3):1-21

Bankina B, Ruza A, Katamadze M, Kreita D, Paura L (2012) Snow mould development under conditions of central part of Latvia. Rural Sustain Res 27(1):1-5. https://doi.org/10.2478/v1023 6-012-0001-6

Bertrand A, Castonguay Y, Cloutier J, Couture L, Hsiang T, Dionne J, Laberge S (2009) Genetic diversity for pink snow mold resistance in greens-type annual bluegrass. Crop Sci 9(2):589-599. https://doi.org/10.2135/cropsci2008.06.0303

Brennan JM, Fagan B, Van Maanen A, Cooke BM, Doohan FM (2003) Studies on in vitro growth and pathogenicity of European Fusarium fungi. Eur J Plant Pathol 109(6):577-587

Brennan JM, Leonard G, Cooke BM, Doohan FM (2005) Analysis of head and leaf reaction towards Microdochium nivale. Eur J Plant Pathol 112(1):79-83

Bruehl GW (1982) Developing wheat resistant to snow mold in Washington State. Plant Dis Rep 66:1090-1095

Bruehl GW, Cunfer BM (1971) Physiologic and environmental factors that affect the severity of snow mold of wheat. Phytopathology 61:792-799

Chang SW, Scheef E, Abler RAB, Thomson S, Johnson P, Jung G (2006) Distribution of Typhula spp. and Typhula ishikariensis varieties in Wisconsin, Utah, Michigan and Minnesota. Phytopathology 96(9):926-933. https://doi.org/10.1094/PHYTO $-96-0926$

Clement JA, Parry DW (1998) Stem-base disease and fungal colonisation of winter wheat grown in compost inoculated with Fusarium culmorum, $F$. graminearum and Microdochium nivale. Eur $\mathbf{J}$ Plant Pathol 104(4):323-330

Cockerell V, Jacks M, McNeil M (2009) Spring cereal seed infection with Microdochium nivale: cause for concern. BCPC Symp Proc 83:95-101

Compant S, Duffy B, Nowak J, Clément C, Barka EA (2005) Use of plant growth-promoting bacteria for biocontrol of plant diseases: principles, mechanisms of action, and future prospects. Appl Environ Microbiol 71(9):4951-4959

Daamen RA, Langerak CJ, Stol W (1991) Surveys of cereal diseases and pests in the Netherlands. 3. Monographella nivalis and
Fusarium spp. in winter wheat fields and seed lots. Neth J Plant Pathol 97(2):105-114

David AS, Haridas S, LaButti K, Lim J, Lipzen A, Wang M, Barry K, Grigoriev IV, Spatafora JW, May G (2016) Draft genome sequence of Microdochium bolleyi, a dark septate fungal endophyte of beach grass. Genome Announc 4(2):e00270-e316

Dempsey JJ, Wilson I, Spencer-Phillips PTN, Arnold D (2014) Phosphite mediated inhibition of the ascomycete pathogens Microdochium nivale and Microdochium majus in the Gramineae. In: Proceedings of Crop Protection in Northern Britain. https ://www.academia.edu/6310871/PHOSPHITE_MEDIATED_ INHIBITION_OF_THE_ASCOMYCETE_PATHOGENS_ MICRODOCHIUM_NIVALE_AND_MICRODOCHIUM_ MAJUS_IN_THE_GRAMINEAE. Accessed 24 June 2020

Doohan FM, Brennan J, Cooke BM (2003) Influence of climatic factors on Fusarium species pathogenic to cereals. In: Xu X, Bailey JA, Cooke BM (eds) Epidemiology of mycotoxin producing fungi. Springer, Dordrecht, pp 755-768

Doohan FM, Parry DW, Jenkinson P, Nicholson P (1998) The use of species-specific PCR-based assays to analyse Fusarium ear blight of wheat. Plant Pathol 47(2):197-205

Dubas E, Golebiowska G, Zur I, Wedzony M (2011) Microdochium nivale (Fr., Samuels \& Hallett): cytological analysis of the infection process in triticale $(\times$ Triticosecale Wittm.). Acta Physiol Plant 33(2):529-537

Dyda M, Wąsek I, Tyrka M, Wędzony M, Szechyńska-Hebda M (2019) Local and systemic regulation of PSII efficiency in triticale infected by the hemibiotrophic pathogen Microdochium nivale. Physiol Plant 165(4):711-727

Edwards SG (2004) Influence of agricultural practices on Fusarium infection of cereals and subsequent contamination of grain by trichothecene mycotoxins. Toxicol Lett 153(1):29-35

Einax E, Voigt K (2003) Oligonucleotide primers for the universal amplification of $\beta$-tubulin genes facilitate phylogenetic analyses in the regnum fungi. Org Divers Evol 3(3):185-194

Ergon Å, Klemsdal SS, Tronsmo AM (1998) Interactions between cold hardening and Microdochium nivale infection on expression of pathogenesis-related genes in winter wheat. Physiol Mol Plant Pathol 53(5-6):301-310

Ergon E, Skinnes H, Tronsmo AM (2003) Testing snow mould resistance of winter wheat: Inoculation experiments with Microdochium nivale in the field. Acta Agric Scand Sect B -Soil Plant Sci 53(3):110-117

Fowler DB, Byrns BM, Greer KJ (2014) Overwinter low-temperature responses of cereals: analyses and simulation. Crop Sci 54(6):2395-2405

Fries EM (1825) Systema Orbis Vegetabilis. I. Plantae homonemeae, Typographia Academica, Lund

Gagkaeva T, Gavrilova O, Orina A et al (2019) Analysis of toxigenic Fusarium species associated with wheat grain from three regions of Russia: Volga, Ural, and West Siberia. Toxins 11(5):252

Gagkaeva TY, Gavrilova OP, Orina AS (2017) The good news is that Microdochium fungi do not produce mycotoxins! Prot Quar Plants 5:9-13 ((in Russian))

Gagkaeva TY, Orina AS, Gavrilova OP, Gogina NN (2020) Evidence of Microdochium fungi associated with cereal grains in Russia. Microorganisms 8(3):340

Gams W, Müller E (1980) Conidiogenesis of Fusarium nivale and Rhynchosporium oryzae and its taxonomic implications. Neth J Plant Path 86(1):45

Gaudet D, Laroche A (2013) Mechanisms of snow mold resistance in wheat. In: Imai R, Yoshid M, Matsumoto N (eds) Plant and microbe adaptations to cold in a changing world. Springer, New York, pp 319-330

Gaudet DA (1994) Progress towards understanding interactions between cold hardiness and snow mold resistance 
and development of resistant cultivars. Can J Plant Pathol 16(3):241-246

Gaudet DA, Bhalla MK (1988) Survey for snow mold diseases of winter cereals in central and northern Alberta, 1983-87. Can Plant Dis Surv 68(1): 15-22

Gaudet DA, Kozub GC (1991) Screening winter wheat for resistance to cottony snow mold under controlled conditions. Can J Plant Sci 71(4):957-965

Gaudet DA, Laroche A, Yoshida M (1999) Low temperature-wheatfungal interactions: a carbohydrate connection. Physiol Plant 106(4):437-444

Gaudet DA, Wang Y, Frick M, Puchalski B et al (2011) Low temperature induced defence gene expression in winter wheat in relation to resistance to snow moulds and other wheat diseases. Plant Sci 180(1):99-110

Gerlach W, Nirenberg H (1982) The genus Fusarium — a pictorial atlas. Mitteilungen aus der Biologischen Bundesanstalt für Land- und Forstwirtschaft Berlin-Dahlem 209:1-406

Glinushkin AP, Ovsyankina AV, Kiseleva MI, Kolomiets TM (2018) Distribution of fungi from the genus Fusarium link on cereals. Russ Agricult Sci 44:235-240 (in Russian). https://doi. org/10.3103/S1068367418030059

Glynn NC, Hare MC, Edwards SG (2008) Fungicide seed treatment efficacy against Microdochium nivale and M. majus in vitro and in vivo. Pest Manage Sci 64(8):793-799

Glynn NC, Parry DW, Edwards SG (2005) Phylogenetic analysis of EF-1 alpha gene sequences from isolates of Microdochium nivale leads to elevation of varieties majus and nivale to species status. Mycol Res 109(8):872-880

Gołębiowska G, Wędzony M (2009) Cold-hardening of winter triticale (x Triticosecale Wittm.) results in increased resistance to pink snow mold Microdochium nivale (Fr., Samuels \& Hallett) and genotype-dependent chlorophyll fluorescence modulations. Acta Physiol Plant 31(6): 1219

Gołebiowska GJ, Bonar E, Emami K, Wędzony M (2019) Cold-modulated small proteins abundance in winter triticale (x Triticosecale, Wittm.) seedlings tolerant to the pink snow mold (Microdochium nivale, Samuels and Hallett) infection. Acta Biochim Pol 66(3):343-350

Gołebiowska-Pikania G, Golemiec E (2015) Cold-enhanced gene expression of the foliar thiol-specific antioxidant protein in triticale (x Triticosecale Wittm.). Seedlings resistant to Microdochium nivale (Samuels and IC Hallett) infection. Zeszyty Naukowe Uniwersytet Szczeciński. Acta Biol 22:98-117. https://doi. org/10.18276/ab.2015.22-08

Gorkovenko VS, Oberyuhtina LA, Kurkina EA (2009) The harmfulness of the Microdochium nivale in agrocenosis of winter wheat. Prot Quar Plants 1:34-35 (in Russian)

Gossen BD, Hsiang T, Murray TD (2001) Managing snow mold diseases of winter cereals and turf. In: Iriki $\mathrm{N}$ et al (eds) Low temperature plant-microbe interactions under snow. Hokkaido National Agriculture Research Station, Sapporo, Japan, pp 181-192

Grosch R, Schumann K (1993) Aggressiveness behaviour of Microdochium nivale Samuels \& Hallett of forage grasses. Arch Phytopathol Plant Prot 28(2):139-146 (in German)

Haas D, Défago G (2005) Biological control of soil-borne pathogens by fluorescent pseudomonads. Nat Rev Microbiol 3(4):307-319

Hayashi Y, Kozawa T, Aiuchi D, Koike M, Akino S, Kondo N (2014) Population genetic structure of Microdochium majus and Microdochium nivale associated with Fusarium head blight of wheat in Hokkaido. Japan Eur J Plant Path 140(4):787-795

Hernández-Restrepo M, Groenewald JZ, Crous PW (2016) Taxonomic and phylogenetic re-evaluation of Microdochium, Monographella and Idriella. Persoonia Mol Phylogeny Evol Fungi 36:57-82
Herter CP, Ebmeyer E, Kollers S, Korzun V, Würschum T, Miedaner $\mathrm{T}$ (2019) Accuracy of within-and among-family genomic prediction for Fusarium head blight and Septoria tritici blotch in winter wheat. Theor Appl Genet 132(4):1121-1135

Hofgaard IS, Vollsnes AV, Marum P, Larsen A, Tronsmo AM (2003) Variation in resistance to different winter stress factors within a full-sib family of perennial ryegrass. Euphytica 134(1):61-75

Hömmö L, Pulli S (1993) Winterhardiness of some winter wheat (Triticum aestivum), rye (Secale cereale), triticale (x Triticosecale) and winter barley (Hordeum vulgare) cultivars tested at six locations in Finland. Agric Food Sci 2(4):311-327

Hömmö LM (1994) Screening winter rye cultivars for snow mould (Microdochium nivale) resistance. Plant Pathol 43(4):740-750

Hömmö LM (1996) Resistance of winter cereals to various winter stress factors: Inter-and intraspecific variation and the role of cold acclimation. Agric and Food Sci 3(Suppl):1-32 (in Russian)

Hoshino T, Morita H, Fujiwara M et al (2004) Heat resistant biocontrol agents against snow molds (Typhula incarnata and $T$. ishikariensis) in various materials from several cold regions. In: Proceedings of international symposium on identification and use of microbial resources for sustainable agriculture. National Agricultural Research Center for Kyushu Okinawa Region, pp 86-87

Hsiang T, Wu C, Cook S (1999) Residual efficacy of Typhula phacorrhiza as a biocontrol agent of grey snow mold on creeping bentgrass. Can J Plant Pathol 21(4):382-387

Hudec K, Muchova D (2010) Influence of temperature and species origin on Fusarium spp. and Microdochium nivale pathogenicity to wheat seedlings. Plant Prot Sci 46(2):59-65

Hudec K, Roháčik T (2003) Fusarium spp. and Microdochium nivale infestation of asymptomatic wheat kernels in Slovakia. Cereal Res Commun 31(3-4):415-420

Humphreys J, Cooke BM, Storey T (1995) Effects of seed borne Microdochium nivale on establishment and grain yield of winter-sown wheat. Plant Varieties Seeds 8:107-117

Iriki N, Kuwabara T (1993) Half diallel analysis of field resistance of winter wheat (Triticum aestivum) to Typhula ishikariensis biotype A in artificially infested plots. Jpn J Breed 43(4):495-501

Ivaschenko VG, Shipilova NP, Nesterov AN, Gagkaeva TY, Nazarovskaya LA, Hlopunova LB (1997) Biological and phytosanitary aspects of Fusarium head blight study. Mikol Fitopatol 31:58-63 (in Russian)

Jamalainen EA (1974) Resistance in winter cereals and grasses to low-temperature parasitic fungi. Annu Rev Phytopathol 12(1):281-302

Jewel LE. 2013. Genetic and pathogenic differences between Microdochium nivale and Microdochium majus. $\mathrm{PhD}$ thesis. University of Guelph, Guelph, Ontario, Canada. https://atrium.lib.uoguelph. ca/xmlui/bitstream/handle/10214/7721/Jewell_Linda_201312_ PhD.pdf?sequence $=3$. Accessed 12 October 2020

Jewell LE, Hsiang T (2013) Multigene differences between Microdochium nivale and Microdochium majus. Botany 91:99-106

Johansson PM, Johnsson L, Gerhardson B (2003) Suppression of wheat-seedling diseases caused by Fusarium culmorum and Microdochium nivale using bacterial seed treatment. Plant Pathol 52(2):219-227

Jonavičienė A, Supronienė S, Semaškienė R (2016) Microdochium nivale and $M$. majus as causative agents of seedling blight in spring cereals. Zemdirbyste-Agricult 103(4):363-368.

Jones SS, Lyon SR, Balow KA et al (2010) Registration of 'Xerpha' wheat. J Plant Regist 4(2):137-140

Jones SS, Murray TD, Lyon SR, Morris CF, Line RF (2001) Registration of 'Bruehl' wheat. Crop Sci 41(6):2006-2008

Jørgensen LN, Nielsen LK, Nielsen BJ (2012) Control of seedling blight in winter wheat by seed treatments-impact on emergence, crop stand, yield and deoxynivalenol. Acta Agric Scand 
B Soil Plant Sci 62(5):431-440. https://doi.org/10.1080/09064 710.2011 .641028

Kabak B, Dobson ADW, Var I (2006) Strategies to prevent mycotoxin contamination of food and animal feed: a review. Crit Rev Food Sci Nutr 46(8):593-619

Kang Z, Huang L, Buchenauer H (2004) Ultrastructural and cytochemical studies on infection of wheat spikes by Microdochium nivale. J Plant Dis Prot 111(4):351-361

Kawakami A, Yoshida M (2012) Graminan breakdown by fructan exohydrolase induced in winter wheat inoculated with snow mold. J Plant Physiol 169(3):294-302

Kiyomoto RK (1987) Carbon dioxide exchange and total nonstructural carbohydrate in soft white winter wheat cultivars and snow mold resistant introductions. Crop Sci 27(4):746-752

Kleijer G (1988) Resistance of Swiss wheat cultivars to snow mould. Revue Suisse d'Agriculture 20:65-67

Kobylyansky VD, Solodukhina OV (2012) Development of N.I. Vavilov's ideas in modern researches of genus Secale L. Proc Appl Bot Genet Breed 169:53-64 (in Russian)

Kondo H, Hanada Y, Sugimoto H et al (2012) Ice-binding site of snow mold fungus antifreeze protein deviates from structural regularity and high conservation. Proc Natl Acad Sci USA 109(24):9360-9365

Kovi MR, Abdelhalim M, Kunapareddy A et al (2016) Global transcriptome changes in perennial ryegrass during early infection by pink snow mould. Sci Rep 6(1):1-15

Kruse EB, Carle SW, Wen N, Skinner DZ, Murray TD, Garland-Campbell KA, Carter AH (2017) Genomic regions associated with tolerance to freezing stress and snow mold in winter wheat. G3 Genes Genomes Genet 7(3):775-780

Kruse EB, Esvelt Klos KL, Marshall JM, Murray TD, Ward BP, Carter AH (2019) Evaluating selection of a quantitative trait: snow mold tolerance in winter wheat. Agrosyst GeoSci Environ 2(1):190059. https://doi.org/10.2134/age2019.07.0059

Kuwabara T, Abe J, Iriki N, Tsuchiya T, Nakajima T (1996) New genetic resources for resistance to snow molds in wheat (Triticum aestivum L.). Jpn J Breed 46(4):409-411

Kuwabara C, Imai R (2009) Molecular basis of disease resistance acquired through cold acclimation in overwintering plants. $\mathrm{J}$ Plant Biol 52(1):19-26

Laroche A, Gaudet DA, Audy P, Frick MM, Mullin J (1997) Induction of freezing tolerance and snow mould resistance in winter wheat: biochemical and molecular perspectives. Acta Agron Hung 45:279-284

Lees AK, Nicholson P, Rezanoor HN, Parry DW (1995) Analysis of variation within Microdochium nivale from wheat: evidence for a distinct sub-group. Mycol Res 99(1):103-109

Levenfors JP, Eberhard TH, Levenfors JJ, Gerhardson B, Hökeberg M (2008) Biological control of snow mould (Microdochium nivale) in winter cereals by Pseudomonas brassicacearum, MA250. Biocontrol 53(4):651-665

Litschko L, Burpee LL (1987) Variation among isolates of Microdochium nivale collected from wheat and turfgrasses. Trans $\mathrm{Br}$ Mycol Soc 89(2):252-256

Lozada D, Godoy JV, Murray TD, Ward BP, Carter AH (2019) Genetic dissection of snow mold tolerance in US Pacific Northwest winter wheat through genome-wide association study and genomic selection. Front Plant Sci 10:1337. https://doi.org/10.3389/ fpls.2019.01337

Matsumoto N (2009) Snow molds: a group of fungi that prevail under snow. Minireview Microbes Environ 24(1):14-20. https://doi. org/10.1264/jsme2.ME09101

Matsumoto N, Hoshino T (2008) Fungi in snow environments: psychrophilic molds. A group of pathogens affecting plants under snow. In: Misra JK, Deshmukh SK (eds) Fungi from different environments. CRC Press, Taylor and Francis Group, Boca Raton, pp 169-188

Matsumoto N, Hoshino T (2013) Change in snow mold flora in eastern Hokkaido and its impact on agriculture. In: Imai R, Yoshida M, Matsumoto N (eds) Plant and microbe adaptations to cold in a changing world. Springer, New York, pp 255-261

Matsumoto N, Hsiang T (2016) Snow mold. Springer, Singapore. https ://doi.org/10.1007/978-981-10-0758-3

Matušinsky P, Kozawa T, Aiuchi D, Koike M, Akino S, Kondo N (2019) Population genetic structure of Microdochium majus and Microdochium nivale associated with foot rot of cereals in the Czech Republic and adaptation to penthiopyrad. Eur J Plant Path 155(1):1-12

Maurin N, Saur L, Capron G (1995) Stem and head reaction of winter wheat cultivars to artificial inoculation by Microdochium nivale under controlled environment and field conditions. Euphytica 92(3):359-366

McBeath JH (2002) Snow mold-plant-antagonist interactions: survival of the fittest under the snow. The Plant Health Instructor. https:// doi.org/10.1094/PHI-I-2002-1010-01

McKey HC, Reader JM (1953) Snow mold damage in Idaho's winter wheat. Idaho Agric Exp Stn Bull 200:1-5

McNeil M, Mackie J, Cockerell V (2012) The effect of Microdochium nivale and $M$. majus on the establishment of spring barley and oats: evidence of host preference. In: The Dundee conference. Crop Protection in Northern Britain, Dundee, UK, 28-29 February 2012. The Association for Crop Protection in Northern Britain, pp 187-192

Meguro-Maoka A, Yoshida M (2016) Analysis of seasonal expression levels of wheat fructan exohydrolase (FEH) genes regulating fructan metabolism involved in wintering ability. J Plant Physiol 191:54-62

Miedaner T, Höxter H, Geiger HH (1993) Development of a resistance test for winter rye to snow mold (Microdochium nivale) under controlled environment conditions in regard to field inoculations. Can J Bot 71(1):136-144

Miedaner T, Beyer W, Höxter H, Geiger HH (1995) Growth stage specific resistance of winter rye to Microdochium nivale and Fusarium spp. in the field assessed by immunological methods. Phytopathology 85:416-421

Miedaner T, Wilde P (2019) Selection strategies for disease-resistant hybrid rye. In: Ordon F, Friedt W (eds) Advances in breeding techniques for cereals. Burleigh Dodds Science Publishing, Cambridge, pp 223-246

Miedaner T, Korzun V, Bauer E (2019) Genomics-based hybrid rye breeding. In: Miedaner T, Korzun V (eds) Applications of genetic and genomic research in cereals. Elsevier, Amsterdam, pp 329-348

Mohammad F, Windes JM, Souza E (1997) Total non-structural carbohydrates in winter wheat populations segregating for snow mold tolerance. Crop Sci 37(1):108-112

Murray TD, Jones S, Adams E (1999) Snow mold diseases of winter wheat in Washington. Washington State University Cooperative Extension and the U.S. Department of Agriculture, Seattle, Pullman, EBI880, pp 1-8

Nakajima T, Abe J (1994) Development of resistance to Microdochium nivale in winter wheat during autumn and decline of the resistance under snow. Can J Bot 72(8):1211-1215

Nakajima T, Abe J (1996) Environmental factors affecting expression of resistance to pink snow mold caused by Microdochium nivale in winter wheat. Can J Bot 74(11):1783-1788

Nicholson P, Lees AK, Maurin N, Parry DW, Rezanoor HN (1996) Development of a PCR assay to identify and quantify Microdochium nivale var. nivale and Microdochium nivale var. majus in wheat. Physiol Mol Plant Pathol 48(4):257-271 
Nielsen LK, Jensen JD, Nielsen GC, Jensen JE, Spliid NH, Thomsen IK, Jørgensen LN (2011) Fusarium head blight of cereals in Denmark: species complex and related mycotoxins. Phytopathology 101(8):960-969

Nielsen LK, Justesen AF, Jensen JD (2013) Microdochium nivale and Microdochium majus in seed samples of Danish small grain cereals. Crop Prot 43:192-200. https://doi.org/10.1016/j.cropr o.2012.09.002

Nissinen O (1996) Analyses of climatic factors affecting snow mould injury in first-year timothy (Phleum pratense L.) with special reference to Sclerotinia borealis. Acta Univ Ouluensis A 289:1-115

Noble M, Montgomerie IG (1956) Griphosphaeria nivalis (Schaffnit) Müller \& von Arx and Leptosphaeria avenaria Weber on oats. Trans Br Mycol Soc 39(4):449-459

Palazzini JM, Torres AM, Chulze SN (2013) Biological control of Fusarium head blight of wheat: from selection to formulation. In: Alconada Magliano TM, Chulze SN (eds) Fusarium head blight in Latin America. Springer, Dordrecht, pp 191-204

Parry DW, Rezanoor HN, Pettitt TR, Hare MC, Nicholson P (1995) Analysis of Microdochium nivale isolates from wheat in the UK during 1993. Ann Appl Biol 126(3):449-455. https://doi. org/10.1111/j.1744-7348.1995.tb05379.x

Peterson CJ Jr, Allan RE, Rubenthaler GL et al (1991) Registration of "Eltan" wheat. Crop Sci 31(6):1707-1708

Płażek A, Dubert F, Pociecha E, Janowiak F, Kolasińska I, Maciejewski M (2011) Resistance of winter rye (Secale cereale L.) to Microdochium nivale depends on soluble carbohydrate content but not on abscisic acid level. J Phytopathol 159(11-12):751-758

Pociecha E, Janowiak F, Dubas E, Żur I, Tokarz K, Kolasińska I, Płażek A (2013) Progress of snow mould infection in crowns of winter rye (Secale cereale L.) is related to photosynthetic activity during cold acclimation. Plant Physiol Biochem 70:360-367

Pociecha E, Płażek A, Janowiak F, Dubert F, Kolasińska I, Irla M (2013) Factors contributing to enhanced pink snow mould resistance of winter rye (Secale cereale L.)-Pivotal role of crowns. Physiol Mol Plant Pathol 81:54-63

Ponomareva ML, Ponomarev SN, Mannapova GS, Ilalova LV (2019) Phytosanitary monitoring of the most harmful winter rye diseases in the Tatarstan Republic. Vestnik Krasnoyarsk State Agricultural University 9:150 (in Russian)

Prończuk M, Madej L, Kolasińska I (2003) Research for resistance to Microdochium nivale among inbred lines of rye. Plant Breed Seed Sci 48:83-86

Prończuk M, Prończuk S (1987) Usefulness of the "cold storage method" in assessing the resistance of ryegrass to Fusarium nivale (Fr) Ces. Biul IHAR 162:27-32 (in Polish)

Pulli S, Hjortsholm K, Larsen A et al (1996) Development and evaluation of laboratory testing methods for winterhardiness breeding. Publications-Nordic Gene Bank 32:1-68

Ren R, Yang X, Ray RV (2015) Comparative aggressiveness of Microdochium nivale and M. majus and evaluation of screening methods for Fusarium seedling blight resistance in wheat cultivars. Eur J Plant Pathol 141:281-294. https://doi.org/10.1007/s1065 8-014-0541-3

Review (2020) Review of the phytosanitary status of crops in the Russian Federation in 2019 and forecast of the harmful object's development in 2020. Ministry of Agriculture of the Russian Federation, Russian Agricultural Centre, Moscow, 2020. https:// rosselhoscenter.com/files/users/42/Moskva/2020/Обзор_2019_ ИТОГОВЫЙ_29f29.pdf. Accessed 29 June 2020 (in Russian)

Samuels GJ, Hallett IC (1983) Microdochium stoveri and Monographella stoveri, new combinations for Fusarium stoveri and Micronectriella stoveri. Trans Br Mycol Soc 81(3):473-483

Schlegel RH (2013) Rye: genetics, breeding, and cultivation. CRC Press, Boca Raton
Serenius M, Huusela-Veistola E, Avikainen H, Pahkala K, Laine A (2005) Effects of sowing time on pink snow mould, leaf rust and winter damage in winter rye varieties in Finland. Agric Food Sci 14(4):362-376

Sheshegova TK (2015) Analysis of the phytosanitary condition of spring grain crops in the Kirov region (analytical review). Agric Sci Euro-North-East 5:10-14 (in Russian)

Simpson DR, Rezanoor HN, Parry DW, Nicholson P (2000) Evidence for differential host preference in Microdochium nivale var. majus and Microdochium nivale var. nivale. Plant Pathol 49(2):261268. https://doi.org/10.1046/j.1365-3059.2000.00453.x

Simpson DR, Weston GE, Turner JA, Jennings P, Nicholson P (2001) Differential control of head blight pathogens of wheat by fungicides and consequences for mycotoxin contamination of grain. Eur J Plant Path 107(4):421-431

Smiley RW, Dernoeden PH, Clarke BB (1992) Compendium of turfgrass diseases, 2nd edn. APS, St. Paul

Smith JD (1981) Snow molds of winter cereals: guide for diagnosis, culture, and pathogenicity. Can J Plant Pathol 3(1):15-25

Smith JD (1983) Fusarium nivale (Gerlachia nivalis) from cereals and grasses: is it the same fungus? Can Plant Dis Surv 63(1):25-26

Smith JD, Jackson N, Woolhouse AR (1989) Fungal diseases of amenity turf grasses. E \& FN Spon, London, New York

Sonia E, Dorothée S, Sandrine G, Corinne C, Christian L, Henri LM, Valérie L (2018) Optimized real time QPCR assays for detection and quantification of Fusarium and Microdochium species involved in wheat head blight as defined by MIQE guidelines. bioRxiv: 272534 .

Stricker S, Hsiang T, Bertrand A (2017) Reaction of bentgrass cultivars to a resistance activator and elevated $\mathrm{CO}_{2}$ levels when challenged with Microdochium nivale, the cause of Microdochium patch. Int Turfgrass Soc Res J 13:229-234. https://doi.org/10.2134/itsrj 2016.08.0666

Sugiyama S, Shimazaki T (2007) Increased cell-wall mass and resistance to freezing and snow mold during cold acclimation of winter wheat under field conditions. Plant Prod Sci 10(4):383-390

Sunderman DW (1964) Modifications of the Cormack and Lebeau technique for inoculating winter wheat with snow mold-causing Typhula species. Plant Dis Rep 48:394-395

Szechyńska-Hebda M, Hebda M, Mierzwiński D, Kuczyńska P et al (2013) Effect of cold-induced changes in physical and chemical leaf properties on the resistance of winter triticale $(\times$ Triticosecale) to the fungal pathogen Microdochium nivale. Plant Pathol 62(4):867-878

Szechyńska-Hebda M, Hebda M, Mirek M, Miernik K (2016) Coldinduced changes in cell wall stability determine the resistance of winter triticale to fungal pathogen Microdochium nivale. J Therm Anal Calorim 126(1):77-90

Tkachenko OB, Ovsyankina AV, Shchukovskaya AG (2015) Snow molds: history of the study and control. Agric Biol 50(1):16-29. https://doi.org/10.15389/agrobiology.2015.1.16eng

Tronsmo AM (1994) Effect of different cold hardening regimes on resistance to freezing and snow mould infection in timothy varieties of different origin. Crop adaptation to cool climates European commission, Brussels (ECSP-EEC-EAEC), Belgium, pp 83-89

Tronsmo AM (2013) Snow moulds in a changing environment-a Scandinavian perspective. In: Imai R, Yoshida M, Matsumoto N (eds) Plant and microbe adaptations to cold in a changing world. Springer, New York, pp 305-317

Tronsmo AM, Hsiang T, Okuyama H, Nakajima T et al (2001) Low temperature plant microbe interactions under snow. Hokkaido National Agricultural Experiment Station, Japan 7:75-85

Utkina EI, Kedrova LI, Parfenova ES (2017) Sources of breeding-valuable traits for creation of winter hardiness varieties of winter rye in Volga-Vyatka region. Int J Appl Fund Res 12-2:326-330 
Utkina EI, Kedrova LI, Parfyonova ES, Shamova MG (2019) Influence of snow mold on winter rye productivity in the Kirov region. Agric Sci Euro-North-East 20(4):315-323 (in Russian). https:// doi.org/10.30766/2072-9081.2019.20.4.315-323

Vavilov NI (1964) Problems of immunity of cultivated plants, vol 4. Nauka, Moscow (in Russian)

Walker AS, Auclair C, Gredt M, Leroux P (2009) First occurrence of resistance to strobilurin fungicides in Microdochium nivale and Microdochium majus from French naturally infected wheat grains. Pest Manage Sci 65(8):906-915. https://doi.org/10.1002/ ps. 1772

Watanabe M, Yonezawa T, Lee KI, Kumagai S, Sugita-Konishi Y, Goto K, Hara-Kudo Y (2011) Molecular phylogeny of the higher and lower taxonomy of the Fusarium genus and differences in the evolutionary histories of multiple genes. BMC Evol Biol 11(1):322

Wollenweber HW (1931) Fusarium monograph. Parasitic and saprophytic fungi. Z Parasitenkunde 3(3):269-516 (in German)

Xu XM, Monger W, Ritieni A, Nicholson P (2007) Effect of temperature and duration of wetness during initial infection periods on disease development, fungal biomass and mycotoxin concentrations on wheat inoculated with single, or combinations of. Fusarium species Plant Pathol 56(6):943-956
Yang C, Hamel C, Vujanovic V, Gan Y (2011) Fungicide: modes of action and possible impact on nontarget microorganisms. ISRN Ecol 2011:130289

Yoshida M, Kawakami A (2013) Molecular analysis of fructan metabolism associated with freezing tolerance and snow mold resistance of winter wheat. In: Imai R, Yosid M, Matsumoto N (eds) Plant and microbe adaptations to cold in a changing world. Springer, New York, pp 231-243

Żur I, Gołębiowska G, Dubas E et al (2013) $\beta$-1,3-glucanase and chitinase activities in winter triticale during cold hardening and subsequent infection by Microdochium nivale. Biologia 68(2):241-248

Żur IA, Dubas E, Pociecha E, Dubert F, Kolasińska I, Płażek A (2011) Cytological analysis of infection process and the first defence responses induced in winter rye (Secale cereale L.) seedlings inoculated with Microdochium nivale. Physiol Mol Plant Pathol 76(3-4):189-196

Publisher's Note Springer Nature remains neutral with regard to jurisdictional claims in published maps and institutional affiliations. 